\title{
Obituaries
}

\section{Thure von Uexküll}

A pioneer of psychosomatic medicine

Almost every German university hospital has a chair of psychosomatic medicine, German medical students are obliged to attend courses in medical psychology, sociology, and psychosomatic medicine, and more than 7000 beds in German rehabilitation hospitals are devoted to the treatment of patients with psychosomatic disorders. The unique position of psychosomatic medicine in Germany-in comparison with other European countries-is largely down to the continuous engagement of Thure von Uexküll.

His aim was to practise integrative medicine: organic and psychological problems should be treated together and not by experts from separate disciplines. It was his credo that no disease was solely caused or influenced by either somatic or psychosocial causes. Von Uexküll believed that the progression of a disease depended just as much on the personality, attitude, and the social circumstances of a patient as on his or her medical condition.

Von Uexküll's view of the human being as a system in the environment of other systems was profoundly influenced by the ideas of his father, the eminent biologist and philosopher Jakob von Uexküll. Born in Heidelberg in 1908, Thure von Uexküll studied medicine in Hamburg and worked as a junior doctor at the Charité Hospital in Berlin and, from 1943 to 1945, as a military doctor. He refused to join the Nazi party.

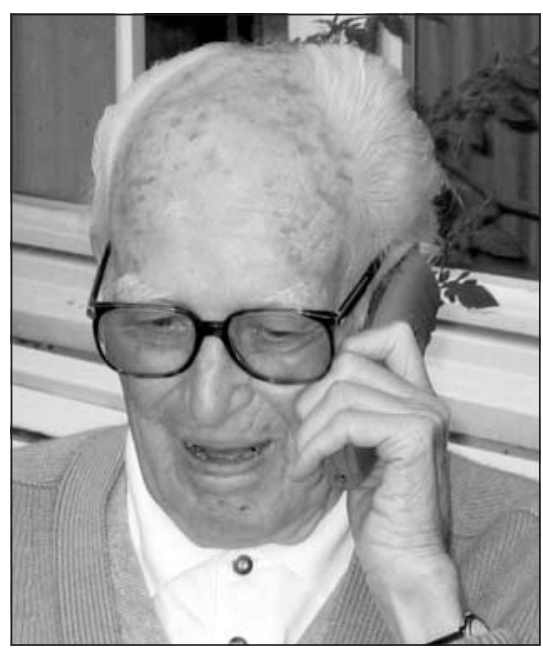

His academic career in medicine and the additional preoccupation with psychoanalysis and psychotherapy began after the second world war at the University Hospital of Munich and was enhanced by his experiences of integrated medical care in the United States, after he was awarded a Rockefeller scholarship.

In 1955 he became medical director, firstly at the recently founded University of Giessen, and later at the University of Ulm. This gave him the chance to practise and establish his idea of integrative medicine, introducing the psychosomatic view of disease to all medical and surgical disci- plines. However, he only partly succeeded. For instance, some of his most prominent co-workers were committed to a more psychoanalytic interpretation of disease and recommended treating somatic conditions such as asthma and stomach ulcers with psychotherapy. Von Uexküll also rejected the introduction of a specialist doctor for psychosomatic medicine and psychotherapy, because he insisted on taking an integral view of the patient.

An important part of von Uexküll's legacy is the firm establishment of psychology, sociology, and psychosomatic medicine as obligatory subjects in the undergraduate medical curriculum. Recent reform of the curriculum puts even more emphasis on doctor-patient communication, further underlining the success of von Uexküll's tireless efforts.

After his retirement in 1976, he wrote and edited Psychosomatische Medizin (Psychosomatic Medicine), which entered its sixth edition last year weighing $2.5 \mathrm{~kg}$ and 1564 pages long. Still fighting for his vision of a medicine that cares for body and soul, in 1992 he founded the Academy for Integrated Medicine in Stuttgart, which helps keep his philosophy alive.

He leaves a wife and a daughter. [Annette Tuffs]

Thure von Uexkül, former professor of psychosomatic medicine Ulm University, Germany (b Heidelberg 1908; $q$ Hamburg 1934), d 29 September 2004.

\section{Dharam Pal Singh Anhal}

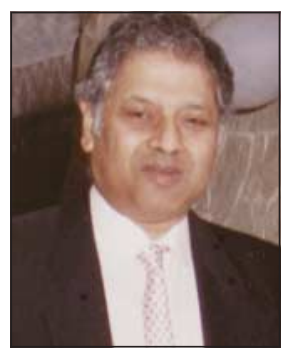

Former general practitioner Luton (b 1937; q Delhi 1961), d 26 August 2004.
Dharam Pal Singh Anhal, known as DP to his friends, came to the United Kingdom in 1962, and worked in east London and at Hillingdon Hospital before entering general practice in Luton in 1965. He built up several practices, with a total of 9000 patients between them. He leaves a wife and three children. [RoHit ANHAL]

\section{Errington Miles Blenkinsopp}

Former general practitioner Thetford (b 1932, $q$ St Mary's Hospital, Paddington, 1958;BA), d 21 September 2004.
After house jobs Miles Blenkinsopp joined the medical arm of the Colonial Service and went out to the West Indies, where he spent 10 years in St Vincent. Returning to England in 1970, he became a general practitioner in Thetford, with clinics in Thetford and Brandon, retiring in 1992. His enthusiasm for golf took Miles and his wife, Gwen, to Portugal in 1972, and they continued to visit there several times a year, building a house in the mountains behind the Algarve. He created superb gardens wherever they went. He leaves Gwen; three children; and five grandchildren. [W K BLENKINSOPP] 


\section{Dennis Geoffrey Brown}

Former psychiatrist, psychoanalyst, and group analyst London (b 1928; q Leeds 1951; MD, FRCPsych, FRCP Ed), d 19 September 2004. Dennis Brown began his medical career in dermatology, eventually turning to psychiatry and psychoanalysis, and ultimately to group analysis. He won a Fulbright Scholarship to Cornell University, during which he became more interested in the psychological aspects of dermatology. In 1969 he joined St George's Hospital, London, as a consultant psychotherapist, later moving to St Mary's Hospital, where he remained until his retirement from the NHS. He was also a member of the Group Analytic Practice, a private clinic specialising in group and family and marital therapies. He leaves a wife, Dorothy, and a son. [Lionel KreEger]

\section{Raymond Colback}

Former consultant anaesthetist Newcastle upon Tyne Hospitals (b Belgian Congo 1931; q Cape Town 1955; DTME H), died from complications of coronary surgery on 26 February 2004.

Raymond, a Belgian citizen, trained in South Africa. He was well ahead of his time in offering day case surgery for children, where surgically feasible. He led the field in shunning conventional premedication and in realising that excessive preoperative starvation was unhelpful, contributing to postoperative nausea. He was fascinated by psychology and psychotherapy, and had a BA in psychology from the Open University. He leaves two sons. [DAvid Cottrell, Philip C Adams]

\section{Katharina Dorothea Dalton}

Former gynaecologist London (b 1916; q London 1948; FRCGP), d 17 September 2004.

Kittie, as she was known, first trained and practised as a chiropodist. Her first husband was killed in action in 1942 and as a widow with one son she studied medicine. On qualifying she began work as a general practitioner in north London. Within months she began to realise that certain symptoms of her women patients came and went with their menstrual cycles - the beginning of her lifelong interest in what she later called the premenstrual syndrome (PMS). In 1957 she was invited to run the world's first PMS clinic at University College Hospital, London, which she continued for over 40 years. Predeceased by her second husband, Tom, she leaves four children and five grandchildren. [SARAh Holton]

\section{Christine Anne Ellington (née Wellard)}

Former general practitioner Altrincham (b 1940; q Royal Free Hospital, London, 1964), died from cardiomyopathy on 2 January 2004. Christine held house appointments at the Royal Free and in Sheffield, where she started her interest in paediatrics. She moved to Altrincham to join a practice housed in an old school attached to the church where her husband, David, was the vicar. She was forced to leave general practice because of prolonged physical debility; this was later followed by intractable depressive illness, but for some time she trained and participated in a counselling career. She leaves David, her children, and her grandchildren. [MARY J LLOYD]

\section{Audrey Irene Freeth}

Former consultant obstetrician and gynaecologist Western Hospital, Glasgow, and Vale of Leven (b London 1913; q Royal Free Hospital, London, 1937; FRCOG), died from bronchopneumonia and cerebrovascular disease on 20 August 2004.

At the Royal Free Hospital she won the Gant gold medal in surgery and the obstetrics prize, and was awarded the HornblowerCock scholarship in medicine to tour the United States. During the second world war she was resident surgical officer at the Birmingham Maternity Hospital, which included training demobilised medical officers for consultant posts. She retired to Auchencairn, Kirkcudbrightshire, where she founded the Minnoch Charitable Trust. [Derek Freeth]

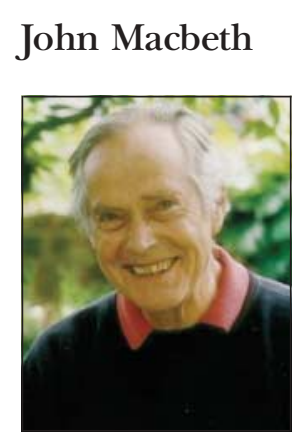

Former general practitioner Chelmsford (b 1920; q London Hospital 1943), d 4 September 2004.

After training at the London Hospital during the Blitz, John Macbeth started his medical practice in Chelmsford from scratch in 1951. Appointed Marconi factory doctor in 1955 and honorary St John Ambulance medical officer soon afterwards, he took on a partner and saw the expansion of the practice continue. There were four partners when he finally stopped work in 1989. He was a founder member of the Royal College of General Practitioners. An accomplished linguist, he refined his knowledge of German in retirement. He also pursued his love of gardening and raised money for the local hospice by growing and selling cyclamen. He leaves a wife, Bonny; four daughters; and six grandchildren. [SOPHIE MACBETH]

+ Longer versions of these obituaries are available on bmj.com

\section{Stanley Arthur Mason}

Former senior anaesthetist King's College Hospital, London (b 1917; q London 1941; FFA RCS, DA, FRCA), died from uraemia and chronic osteoarthritis on 29 July 2004.

Stanley A Mason was a past president of the Association of Anaesthetists. Among his major achievements was his pioneering work in open heart surgery, liver transplant, intensive care units, and kidney and finally lung transplantation. During the second world war he served as an anaesthetist during the Normandy landings, and was mentioned in dispatches for devotion to duty under enemy fire. He was later sent to join the battle still raging in the Far East. Predeceased by his eldest son, he leaves a wife, Marjorie; three sons; and 10 grandchildren. [JEREMY MASON]

\section{Andrew Shannon Ramsey}

Consultant physician Lisburn, Northern Ireland 1951-80 (b Belfast 1915; q Belfast 1939; MD, FRCP,FRCPI), died from cancer on $12 \mathrm{April}$ 2004.

During the second world war he served with the Royal Army Medical Corps in north Africa and Italy. He was in command of a field ambulance, retiring with the rank of lieutenant colonel in 1947. He was awarded an MBE and was mentioned in dispatches. After obtaining further qualifications he was appointed the first consultant physician at the Lagan Valley Hospital. As well as establishing the medical unit there, he was instrumental in raising large sums to build the first coronary care unit in the area. Predeceased by his wife, he leaves two children and two grandchildren. [ELIZABETH RAMSEY]

\section{Andrew Henderson Torrance}

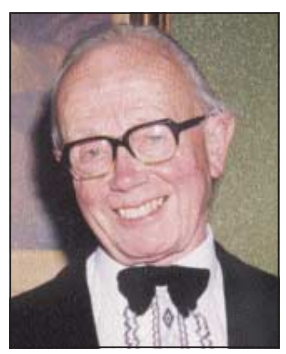

Former general practitioner Hugglescote, Leicestershire (b 1918; q St John's College, Oxford, 1943; FRCGP), d 10 March 2004. Andrew's first job after graduating was at Leicester Royal Infirmary. In 1946 he and his young bride, Dr Lorna Lawrence Duncan, bought a two handed practice at Hugglescote, Leicestershire, just a couple of miles from where he was born. He expanded the practice, finally retiring in 1988. Andrew was president of Leicestershire Medical Society in 1987 and secretary of West Leicestershire Medical Society. Predeceased by his wife, he leaves three children and eight grandchildren. [KeITH ToRRANCE] 